\section{For goodness sake}

\section{Christopher Longuet-Higgins}

From Knowledge to Wisdom: $A$

Revolution in the Aims and Methods of Science.

By Nicholas Maxwell.

Basil Blackwell: 1984. Pp.298. f19.50,

$\$ 29.95$.

THIS book is the work of an unashamed idealist; but it is none the worse for that The author is a philosopher of science who holds the plain man's view that philosophy should be a guide to life, not just a cure for intellectual headaches. He believes, and argues with passion and conviction, that the abysmal failure of science to free society from poverty, hunger and fear is due to a fatal flaw in the accepted aim of scientific endeavour - the acquisition and extension of knowledge.

It is impossible to do Maxwell's argument justice in a few sentences, but, essentially, it is this. At the present time the pursuit of science - indeed the whole of academic inquiry - is largely dominated by "the philosophy of knowledge". At the heart of this philosophy is the assumption that knowledge is to be pursued for its own sake. But the pursuit of objective truth must not be distorted by human wishes and desires, so scientific research becomes divorced from human needs, and a wellintentioned impartiality gives way to a deplorable indifference to the human condition. The only escape is to reformulate the goals of science within a "philosophy of wisdom", which puts human life first and gives "absolute priority to the intellectual tasks of articulating our problems of living, proposing and criticizing possible solutions, possible and actual human actions". The philosophy of wisdom commends itself, furthermore, not only to the heart but to the head: it gives science and scholarship a proper place in the human social order, whereas "standard empiricism" - the most articulate expression of the philosophy of knowledge offers no kind of justification for the pursuit of knowledge, or, indeed, any basis for evaluating its results (that is, for distinguishing between a significant discovery and a trivial assortment of "scientific facts").

Nicholas Maxwell has breached the conventions of philosophical writing by using, with intent, such loaded words as "wisdom", "suffering" and "love". "That which is of value in existence, associated with human life, is inconceivably, unimaginably, richly diverse in character." What an un-academic proposition to flow from the pen of a lecturer in the philosophy of science; but what a condemnation of the academic outlook, that this should be so. Mr Maxwell is advocating nothing less than a revolution (based on reason, not on religious or Marxist doctrine) in our intellectual goals and methods of inquiry. The foundation, in 1662, of the Royal Society of London for Improving Natural Knowledge was not, in that enlightened age, liable to serious misinterpretation; but in our own century the original purpose of the enterprise, defined by Francis Bacon as the enhancement of our power to do good, has been largely forgotten. "How elegant!" is a high compliment to a colleague's work. "How useful!" would be little short of an insult.

There are altogether too many symptoms of malaise in our science-based

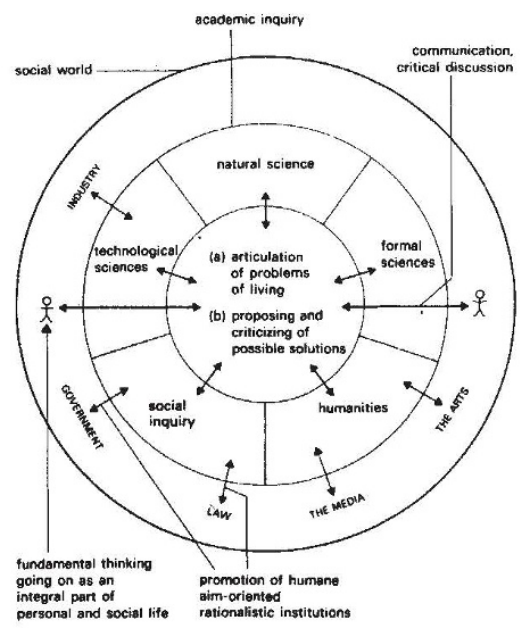

Better relations? Interaction between the intellectual domain of inquiry and the social world according to the philosophy of wisdom.

society for Nicholas Maxwell's diagnosis to be ignored. He fair-mindedly admits that some scientists, of whom Albert Einstein was an outstanding example, do regard their work as a kind of pilgrimage - the goal of which is not mere knowledge but a deeper understanding of the natural world and of our place within it - and that such an attitude is characteristic of the philosophy of wisdom rather than the philosophy of knowledge. But it cannot be claimed that the best scientists have always been men and women of outstanding human qualities. Dr Strangelove is all too credible a villain, the more dangerous because idolatry - the worship of our own handiwork - is no longer regarded as a menace to society. (Would that the computers-in-education people took it more seriously than they seem to.) The dangers are less serious, though, in the more mature sciences, such as mathematics and physics, than in the much-newer social sciences - as their practitioners are pleased to call them. In Mr Maxwell's words:

The central, and tragic, intellectual mistake (according to the philosophy of wisdom) that has bedevilled social inquiry ever since the Enlightenment is illustrated in miniature in an especially graphic and simple way in a book by Barbara Wootton entitled Testament for Social Science (1950). Its subtitle - 'An Essay in the Application of Scientific Method to Human Problems' - might lead one to believe that the book expounds and defends the philosophy of wisdom. But if the first few sentences of the book strengthen this belief, what follows must quickly dispel the idea. The book opens as follows:

'The contrast between man's amazing ability to manipulate his material environment and his pitiful incompetence in managing his own affairs is now as commonplace as it is tragic ... I hope to show that the potential contribution of science in this field is far greater than anything we have seen: the differences between the material of the social and the natural sciences [reviewer's italics] are differences of degree rather than of kind.'

In the 34 years that have followed Barbara Wootton's Testament the social "sciences" have lamentably failed to make people any better because, suggests $\mathrm{Mr}$ Maxwell, they have not even tried; professional etiquette precludes a social "scientist" from making value judgments, from suggesting that anything might be wrong, from recommending any sort of action that might interfere with the system under observation. Mercifully these morally paralysing taboos have not yet overtaken the medical profession, who are commendably outspoken in their protests at, for example, the efforts of the tobacco companies to push the medical researchers back into their laboratories to continue to collect superfluous evidence about a "possible" connection between smoking and lung cancer.

Mr Maxwell is an optimist, and in the last chapter of his admirable book he assures the reader that the revolution is already under way. In the past ten or fifteen years, as he points out, there has been a multitude of developments, within and without the academic world, that can be interpreted as attempts to implement the philosophy of wisdom - Rachel Carson's Silent Spring (1962), Barry Commoner's Science and Survival (1966), the Club of Rome's Report, The Limits to Growth, by Meadows et al., Schumacher's Small is Beautiful, Higgins's The Seventh Enemy and many other seminal writings on the human implications of science. For those of us who practise science, the book's takehome message is that every scientist should ask himself, at every level from the most particular to the most general, exactly why he is doing what he is doing, and whether he would not be better advised to do it differently, or even do something entirely different. Is he content merely to acquire an expertise, which he can sell profitably in the market place; or should he find a vantage point from which he can make sure that his efforts, and those of his colleagues, serve, in the broadest possible sense, the interests of his fellow human beings? If From Knowledge to Wisdom stimulates a serious debate on such issues, it will have served a worthy purpose.

Christopher Longuet-Higgins is Royal Society Research Professor in the Centre for Research on Perception and Cognition, University of Sussex. 